\title{
DEVELOPING AND PROMOTING DISCOVERY LEARNING METHODS IN ESP STUDIES
}

\section{РОЗВИТОК ТА ПРОСУВАННЯ НАВЧАННЯ СТУДЕНТІВ АНГЛІЙСЬКОЇ МОВИ ПРОФЕСІЙНОГО СПРЯМУВАННЯ ШЛЯХОМ МЕТОДУ ВІДКРИТТЯ}

\begin{abstract}
The article deals with developing and promoting discovery learning, analysis and further information synthesis for the students to understand and materialize abstract principles. Attention has been given to this method origin, analysis of the previous researches and publications in the context of student-oriented education. Reference has been made to the relationship between the discovery learning method and problem solving, training of cognitive and regulatory skills. The most critical advantages and disadvantages of this method have been circumscribed relying on theoreti$\mathrm{cal}$ findings of the famous professionals and also pros and cons of some computer subjects' learning, such as programming, websites designing via discovery learning method. The characteristic of the successful usage of discovery learning method for the students that learn a foreign language, English in particular, has been analyzed in the framework of ESL and ESP in the context of intercultural communication; relying upon this method the students can easily find necessary professional information with minimal teacher participation and impact using recommended resources and materials such as scientific papers, experimental data, feedback, internet usage and simulation. It has been found out that the strategy in question helps to introduce successful assessment of students' knowledge as an important element of learning process and successful curriculum provided the teacher is very competent and skilful concerning the forms and strategies of assessment in order to help students use such techniques as planning, reporting about the achievements' results and reaching the learning goal. It was stated that the discovery learning method gives an opportunity to develop critical thinking and creativity while writing their personal texts in different genres with an accent on text organization and linguistic peculiarities and apply this method for strategy implementation of three-phase step-by-step listening working out the material before-, while- and after listening; this method is also related to the so called scientific approach which includes questioning, reasoning, observation and communicative elements. Key words: discovery learning method, methods of teaching, information, problem solving, student-centered learning, knowledge.
\end{abstract}

у статті висвітлено розвиток та просування навчання студентів іноземної мови шляхом методу відкриття, аналізу і подальшого синтезу інфоормації 3 метою розуміння та матеріалізації ними абстрактних принципів. Приділено увагу витокам цього методу, аналізу попередніх досліджень і публікацій у контексті навчання іноземної мови, скерованого на студента. Зроблено акцент на зв'язку методу відкриття і вирішення проблем, тренуванні когнітивних та регулятивних навичок. Окреслено основні переваги і недоліки цього методу, посилаючись на теоретичні дослідження відомих фрахівців, а також плюси і мінуси викладання деяких комп'ютерних предметів, таких як програмування, створення веб-сторінок методом відкриття. Охарактеризовано успішне використання методики навчання шляхом відкриття для студентів, які вивчають другу іноземну мову та іноземну мову за професійним спрямуванням у контексті міжкультурної комунікації: за допомогою цього методу студенти самостійно знаходять потрібну профеесійну інфоормацію з мінімальною участю викладача, використовуючи запропоновані джерела та матеріали, такі як наукові роботи, експериментальні дані, зворотний зв'язок, використання інтернету та моделювання. Виявлено, що ця стратегія викладання допомагає застосувати успішне оцінювання знань студентів як важливий елемент процесу навчання й ефрективної навчальної програми за умови, що викладач має бути дуже компетентним і майстерним щодо форм та стратегіі оцінювання, щоб допомогти студентам використовувати такі методики оцінювання, як планування, звітування про результати досягнень студентів і досягнення мети навчання. Було з'ясовано, що методологія навчання через метод відкриття дає можливість студентам розвинути критичне мислення і креативність під час написання власних текстів у різних жанрах з акцентом на текстову організацію і лінгвістичні особливості, а також використати чей метод для імплементації техніки трифразового слухання крок за кроком, опрацьовуючи матеріал перед, під час і після слухання; цей метод також пов'язаний з так званим науковим підходом, який включає опитування, обгрунтування, спостереження та комунікативність.

Ключові слова: метод відкриття, методи навчання, інформація, вирішення проблем, навчання, скероване на студента, знання.
Stating a problem. It is in 1909 John Dewey, a famous linguist and methodologist wrote about student-centered learning in his book The Child and the Curriculum in which he pointed out that students should have a possibility to investigate, analyze and bring together pieces of information in order to com- prehend abstract principles, materialize them and try to avoid boring while learning.

One of the most critical examples of student-centered learning is the Discovery Learning Method. It is an active, practical style of learning, put forward by Jerome Bruner. Bruner emphasized that we should 
be "learning by doing". Using this method, students should actively take part in the process of learning instead of passively receive information and knowledge. Students will interact with their milieu by investigating and handling objects, solving questions and problems or experimenting. They will be encouraged to think, ask questions, look for answers, consider, reflect and collaborate with others. They will become competent in problem solving and feel confident using knowledge they already have. The Discovery Learning Method is a constructivist theory; it means that the students create their own perception of the world.

Analysis of recent publications. Discovery learning method can go back to scientists like Rousseau, Pestalozzi and Dewey. In particular Dewey's accent on "practice" is in fashion again.

As modern discovery learning methodology is connected with constructivist theory Bruner is treated as a first explorer of discovery learning method by many researchers. For example, in the Encyclopedia of Educational Technology one can read the following Bruner's words "Emphasis on discovery in learning has precisely the effect on the learner of leading him to be a constructionist, to organize what he is encountering in a manner not only designed to discover regularity and relatedness, but also to avoid the kind of information drift that fails to keep account of the uses to which information might have to be put" [4, p. 99].

Another strong impact for some types of discovery learning is that discovery learning method is also strongly connected with problem solving from the point of view of meta-cognitive perspective: F. Borthick and D. Jones write: "Learning theorists characterize learning to solve problems as discovery learning, in which participants learn to recognize a problem, characterize what a solution would look like, search for relevant information, develop a solution strategy, and execute the chosen strategy" [3, p. 181]. Some authors state that discovery learning may enhance content adequacy and student engagement in the context of project-oriented learning. Speaking about the most effective models of discovery learning and technologies used the researchers mention also advantages and disadvantages of the method. As W. Joolingen states the advantages embrace: 1) Collaborative discovery learning; 2) Discovery learning with micro worlds; 3) Experiential learning; 4) Guided discovery learning; 5) Incidental learning; 6) Learning by exploring (exploratory learning); 7) Simulationbased learning; 8) Case-based learning; 9) Problembased learning; 10) Inquiry-based learning [11].

W. Kirshner, J. Sweller and R. Clark highlight typical disadvantages or criticisms that are as follows: 1) Discovery learning has the potential to confuse learners if no initial framework is present; discovery learning is too time consuming for all academic activities (for example mathematical operations), 2) There are not enough hours in an academic year for students to discover everything on their own; sometimes this method creates misconceptions (knowing less after instruction); 3) Discovery learning requires that the teacher be prepared for too many corrections; 4) A lot of things one discovers for oneself turn out to be wrong (the process of trial and error); 5) Discovery learning has limitations in practice when schools try to make it the main way students learn academic lessons [12].

But despite very strong arguments concerning discovery learning models like problem-based learning, the consensus is still not found. It is wise to turn to higher-school science teaching in this context. It is really very serious and it puts a very heavy stress on short-term memory. In order to solve different problems that can be quite sophisticated a person must involve many models in the process and in case there is nothing present in long-term memory, the learner fails.

Researchers R. Amiyani and J. Widjajanti, for example, do not believe that such computer sciences as object-oriented programming could be taught by a discovery method, but making web pages on the other hand could. Students can work on their own projects and tie quite independent concepts like HTML, CSS, Ergonomics, Style, Color etc. on their own speed. A project-oriented approach to web page making probably also would be less effective than a strategy like direct instruction. On the positive side, students involved in discovery with some guiding done by the teacher will be able to find resources, to analyze different texts found on the Internet, for example, to learn something about the economics, to decompose a problem, etc., that is they master some skills that are probably transferable to similar autonomous learning situation [2].

There are a number of issues that we should investigate within the general problem stated in the article. One of the most crucial issues is that discovery learning is quite difficult to implement, since students should acquire some cognitive and discovery skills. They include: 1) hypothesis reconstruction, 2) experiment design, 3) prediction and data analysis. Regulative skills such as planning, monitoring and motivating are also of highest importance for successful discovery learning [10].

So, the aim of the article is to introduce the most effective models of discovery learning method and the ways of its implementation into the academic process.

The main part of the article. While analyzing the discovery learning method and its usage we have investigated that the methodology used consists of three main types: a quantitative research, qualitative method and mixed one. We use three of them with the focus on qualitative method. The quantitative research is used with the purpose of presenting new 
developments in the area of the general language teaching, the so-called generalizability use. The qualitative paradigm is a process of inquiry whose goal is to understand a problem from multiple perspectives [6]. Qualitative research is being locally situated, participant-oriented, holistic and inductive. During the procedure different developments in the context of discovery learning method usage are being mentioned and analyzed: application of the method in question with ESL, and especially ESP students, researching assessment techniques, strategies that increase the discovery learning method in the ESP classroom, stimulate creativity and critical thinking, involve group discussions, role-plays, real-life situations, increase listening and writing skills [6].

The Discovery Learning Method is very attractive for ESL students. The student who is very active in class will have an opportunity to participate in the learning process. The student who studies English as a second language learns to investigate ideas instead of being proposed what to think, very often without understanding the idea because of language obstacles. The Discovery Learning Method is practical; it is keen on the process, and helps students look for decisions. Instead of just teaching students to memorize rules or concepts, this method lets them apply ideas to their lives.

The Discovery Learning Method is part and parcel of teaching methodology in ESP studies. This method recommends the learners to find the needed professional information or concept on their own by the help of proposed sources and materials with minimal teacher's help and advice such as manuals, simulations, feedback, example problems. In the same way, applying this method, teachers do not directly teach the subjects, instead, they facilitate the students to find their own resolutions and discover gist of the problems they are researching by themselves. In such a way, the students pick out the small bits of knowledge, bring them together to achieve the final concept they are looking for [1]. Discovery learning anticipates the students to discover the facts or the contents of the topic via observing and experimenting activities. This teaching strategy also needs to apply proper assessment methodology as an important part of the teaching-learning process and an effective curriculum. Accordingly, the teacher must be very skillful in treating assessment competence to help the students use assessment techniques such as planning, conducting and reporting the results of students' achievements in a proper way and achieve the learning objective. There are some strategies that increase the discovery learning in the ESP classroom such as (a) teach the concept of concepts, (b) name the concepts, (c) browse from concrete to abstract and back, (d) teach reasoning and connect concepts, (e) teach question-answer relationships, (f) include brainstorming activities in the lessons, (g) use teach- ing strategies that switch on critical thinking, (h) focus on feedback generation for students [5]. The development of students' discovery skills occurs as a result of continuous practice involving tasks to stimulate the thinking skills in analyzing information to determine the problem, evaluating the problem and creating new workable solutions [5; 7].

Discovery-based learning methodology is a very important strategy for stimulating students' critical thinking and creativity. Critical thinking is a complex form of thinking activity, it embraces such thinking processes as researching, analyzing, differentiating, picking out, clarifying, assessing, and evaluating more specific ideas to make rational decisions. Because of that the teacher can use high order thinking skills (HOTS) questions. Other strategies to be involved in the process are group discussions, roleplays, real-life situations, which being used improve students' language and speaking skills [13].

Teachers also have to take classes in developmental psychology to properly identify students with developmental problems. Using the Discovery Learning Method helps students with developmental problems to fulfill their different activities during a class. The teachers interact with students in the class to help apply any new skills for solving different problems showing that there is more than one way to get to a conclusion.

A discovery learning approach can be successfully used in the process of teaching writing in ESP studies. It has been suggested by the scientists that the aim of genre-based language teaching is to raise learners' consciousness about the text organization and the linguistic features related to the genre [8]. In the first stage of teaching writing, consciousnessraising tasks are designed with using the discoverybased learning approach based on samples. For example, when the students were taught how to write any text of any genre, samples are proposed to analyze them with the help of guiding questions.

The next stage deals with introducing guidelines and examples. For example, the guidelines and examples can be related to writing reports for technical proposals. The students are shown some samples as examples without keeping them. Such kind of algorithm proceeded through the ESP course would give a chance to develop their creativity and critical thinking while designing and writing their own texts in different genres [8]. In this respect it is very critical to contextualize a text before presenting it to the students that can be done by tackling the aim, participants, institutional peculiarities and values, by discussing linguistic features and their functioning within the context of the text. It is important for teachers to develop students' awareness of how language differs in various situations and how those differences are related to different purposes [9]. In such a way it comes to deal with the so-called scientific approach. 
Discovery learning method can be also used as an appropriate strategy of teaching English while applying three-phase listening method. The three-phase listening method rests on the fact that the students will get needed information and hence knowledge that will help adopt and learn the listening material gradually via the pre-, while-, and post-listening activities.

Conclusion. There are certain preferences in discovery learning models like: (1) this learning model is a part of teaching methodology for ESP students, (2) it includes the techniques that enhance the assessment strategies, critical thinking, creativity, listening and writing skills, (3) this learning model has much to do with the so-called scientific approach that includes observing, questioning, rationalizing, associating, and communicating [7].

All in all, we can say that discovery learning method is a technique highly applied for both ESL and ESP instruction and is considered to be a constructive approach to education. The term "discovery learning" can embrace a great number of teaching techniques from covert sense identification to conducting simulations.

\section{REFERENCES:}

1. Alfieri, Louis, Brooks, Patricia, Aldrich, Naomi, \& Tenenbaum, Harriet. Does Discovery-Based Instruction Enhance Learning? Journal of Educational Psychology. 2011. 103 (1). P. 1-18. doi.org/10.1037/a0021017

2. Amiyani, R., Widjajanti, J.B. Self-confidence and mathematics achievements using guided discovery learning in scientific approach. Journal of physics: conference series. 2019. Vol. 1157, Issue 4.

3. Borthick, F., Jones, D. The Motivation for Collaborative Discovery Learning Online and Its Application in an Information Systems Assurance Course. Issues in Accounting Education. 2000. Vol. 15, No. 2. P. 181-210.
4. Bruner, Jerome. On knowing: Essays for the left hand. Cambridge, Mass: Harvard University Press. 1967.

5. Chinedu, Caleb C., Kamin, Yusri, \& Olabiyi, Oladiran S. Strategies for Improving Higher Order Thinking Skills in Teaching and Learning of Design and Technology Education. Journal of Technical Education and Training. 2015. Vol. 7(2). P. 35-43.

6. Creswell, J.W. Research Design: Qualitative, Quantitative, and Mixed Methods Approaches. $4^{\text {th }}$ ed. Los Angeles: SAGE Publications, Inc., 2014. 342 p.

7. Hassan, Nazri, Mustapha, Ramlee, Nik Azmah Nik Yusuff, Mansor, Rosmidar. Development of Higher Order Thinking Skills Module in Science Primary School: Needs Analysis. International Journal of Academic Research in Business and Social Sciences. 2017. Vol. 7, Issue 2. P. 624-628.

8. Hedge, Tricia. Teaching and Learning in the Language Classroom. New York: Oxford University Press, 2003.

9. Henry, Alex, Roseberry, Robert. An evaluation of a genre-based approach to the teaching of EAP/ESP writing. TESOL Quarterly. 1998. Vol. 32, Issue 1. P. 147-156. doi.org/10.2307/3587913

10. Ho, Belinda. Solving the problems of designing and teaching a packed English for Specific Purposes course. New Horizons in Education. 2011. Vol. 59, No. 1. P. 119-136.

11. Joolingen, W. Cognitive tools for discovery learning. International Journal of Artificial Intelligence in Education. 1999. № 10. P. 385-397.

12. Kirschner, Paul, Sweller, John, \& Clark, Richard. Why minimal guidance during instruction does not work: An analysis of the failure of constructivist, discovery, problem-based, experiential, and inquiry-based teaching. Educational Psychologist. 2006. Vol. 41, Issue 2. P. 75-86.

13.Wahuydi, Dwi. Developing Discovery LearningBased Assessment Module to Stimulate Critical Thinking and Creativity of Students' Speaking Performance. English Education Journal. 2019. Vol. 9(2). P. 172-180. 